\title{
Qualité des eaux marines
}

\author{
Marine and coastal water quality \\ COLLOQUE SHF, PARIS, 22 ET 23 JANVIER 2007 \\ DAMIEN VIOLEAU \\ $\mathrm{EDF}-\mathrm{R} \& \mathrm{D}$ \\ Animateur de la section Hydraulique maritime de la SHF
}

Les médias font régulièrement référence aux accidents maritimes causant d'importantes pollutions du littoral par des hydrocarbures ou des contaminants chimiques, mais la question des "pollutions » marines, plus complexe dans ses enjeux et ses problématiques, est beaucoup plus étendue que ne le suggèrent ces événements médiatisés. Plus généralement, le problème de la qualité des eaux naturelles est amené à prendre de plus en plus d'importance avec le développement industriel et démographique, mais aussi dans la perspective d'un changement climatique. Si le problème est suffisamment aigu dans le milieu fluvial pour avoir amené la Commission Européenne à instaurer la Directive Cadre sur L'Eau (DCE), il est également de première importance dans le domaine maritime, près de la moitié de la population européenne vivant à moins de $50 \mathrm{~km}$ d'un littoral, lequel constitue une grande part du revenu des pays de l'Union grâce aux activités de pêche, de tourisme, d'industrie, de commerce et de transports.

La science qui régit les phénomènes liés à la qualité des eaux marines est complexe pour plusieurs raisons, tout d'abord parce qu'elle met en jeu différentes disciplines de la Physique, de la Chimie et de la Biologie, mais surtout parce qu'on est généralement en présence de phénomènes qui interagissent les uns avec les autres via des échelles de temps et d'espace couvrant un spectre très étendu. Parmi les thèmes clefs entrant dans ce contexte, on trouve bien entendu les hydrocarbures, produits chimiques et substances radioactives, mais aussi le transport de sédiments ainsi que les panaches et fronts thermiques. Enfin, un sujet immense amené à se développer considérablement dans un proche avenir est celui des contaminants biologiques, algues et micro-organismes par exemple. Tous ces thèmes, apparemment disjoints, partagent en réalité le fait de dépendre de phénomènes d'advection et de diffusion turbulente, d'interagir plus ou moins fortement avec des processus spécifiquement maritimes et estuariens tels que la houle, le flux et le reflux, ainsi que les gradients salins. Ce colloque a eu pour objet de présenter des avancées récentes dans chacun de ces domaines, en mettant en évidence le caractère à la fois théorique et appliqué des études menées par plusieurs laboratoires de renommée mondiale. Il vise également à sensibiliser aux nouveaux savoirs et outils disponibles pour progresser dans la connaissance de ces phénomènes.

La section Hydraulique Maritime de la Société hydrotechnique de France a organisé les 22 et 23 janvier 2007 à Paris un colloque sur le thème des pollutions marines, avec pour objectif de permettre aux chercheurs, ingénieurs, décideurs, de partager leurs points de vue et de présenter des avancées innovantes sur quatre sous-thèmes porteurs : les hydrocarbures et les barrages flottants, les pollutions chimiques et radiologiques, la dynamique des bouchons vaseux et des panaches thermiques, enfin le devenir des contaminants biologiques. Ce numéro de
La Houille Blanche et le suivant réunissent quelques-unes des contributions les plus intéressantes à ce colloque.

Media regularly refer to sea wrecks or tanker clean out operations causing high shore pollution impact by oil spills or chemical contaminants. However, the question of marine "pollutions» involve much more complex problems and stakes and cover a larger range than these media events usually suggest. Generally speaking, the problem of water quality in the environment should take a larger importance in the future with industrial development and population growth, not to mention the influence of climate change. This question appeared to be serious enough to incite the EC to establish the well known European Water Directive (EWD), and is of first importance for marine waters. Indeed, one should keep in mind that half of the European population live less than 50 $\mathrm{km}$ to the coastline, which contributes to a large amount of European economic resources through fishing, tourism, industry, business and transportation. The science covering marine water quality phenomena is quite complex for several reasons. Firstly, many disciplines of Physics, Chemistry and Biology are concerned; secondly, we are in presence of highly interacting processes, involving a very wide range of space and time scales. Among the key domains that must be considered in this context, obviously one should mention oil, chemical and radioactive pollutants, but also sediment transport as well as thermal fronts and plumes. Lastly, a whole field of environmental science, probably subject to a high development in the near future, is the behaviour of biological contaminants, e.g. algal blooms and micro-organisms. These themes, apparently disconnected, actually depend on common physical processes like transport, dispersion and turbulent diffusion, and interact more or less with specifically marine and estuarine processes like waves, flood and ebb, and density gradients. This workshop aimed at showing recent progress in these fields, focusing on both theoretical and applied considerations developed by World-recognized research laboratories. It also has the ambition to provide information regarding new scientific methods and available tools required to improve our knowledge and modelling of these phenomena, in order to better anticipate and manage these problemsThe Maritime Hydraulics section of Société Hydrotechnique de France organized on January 22nd and 23rd 2007 in Paris a colloquium on the theme of marine pollutions, whose main goal was to allow researchers, engineers and decision-makers to share their respective point of view and to present innovative advances on four decisive sub-themes: oil spills and containment booms, chemical and radiological pollutants, turbidity maxima and thermal plumes, and eventually biological contaminants. This issue of La Houille Blanche, and the next one, contains some of the most significant contributions to this colloquium. 